\title{
The Balinese Cooking and Language Class as a Tourism Attraction of Special Interest
}

\author{
Francisca Titing Koerniawaty, Ni Komang Nariani, I Made Sudjana \\ Sekolah Tinggi Pariwisata Bali Internasional \\ Denpasar, Indonesia \\ koe.titing@gmail.com
}

\begin{abstract}
The study aim is to design and develop the Balinese cooking and language class as a tourism attraction of special interest in Bedulu, Gianyar Bali to create an atmosphere that is really close to Balinese culture, in turn will create a travel experience which is more experimental and memorable for the visitors. All Balinese ingredients will be introduced in Balinese language. The urgency of this study are as follows: (1) there is potential in Bedulu village as a tourism attraction that is unique and leads to special interest destination through some of the cultural heritage and beauty of nature, (2) the cooking class that has been presented needs to be developed further so that the visitors can obtained a travel experience which is more experimental and memorable through the participation of local communities, (3) the geographical location of Bedulu village which can be positioned as the area of special interest tourism destination of educational and cultural. This research method is Design and Development Reserach. This study is to design and develop systematically from the process of designing and developing the Balinese cooking by introducing several Balinese terminologies in cooking. The Balinese cooking class should be designed and developed by considering the hygiene and sanitation standards, health and benefit.
\end{abstract}

Keywords - Balinese cooking and language class, tourism attraction of special interest

\section{INTRODUCTION}

Bedulu is located in tourism area of Tampak SiringPanelokan-Trunyan that is well known, is arround 45 minutes from Denpasar.'Pakraman' Bedulu village is one of villages in sub district of Blahbatuh in Gianyar regency, Bali, is located at coodinate S. 8 31' 46.6" E. 115 17'26.1" with the height above sea level 170 meters. The teritory is spacious with the total population-823 head of family. It has three of Kahyangan temples dan other temples which reserve some of archeological heritage. The 'Pakraman' Bedulu village consists of 5 villages such as 'banjar' Margabingung, Tengah, Batulumbung, Lebah and Goa village.

The tourism in this village is based on the community that involves pilgrim, education, cultural and nature tourism. The educational and cultural tourism management in this village was handled homely. It needs more improvement to create the visitors experimental and memorable experience.
One of a tourism attraction of special interest is cooking class can be offered to attract the tourists to visit the tourism detination like Bedulu village. In several hotels and tourism destination has been designed and developed a special interest of tourism like cooking class with their various program.

Based on the beauty and fertility of nature of Bedulu village, this study aim is to design and develop a Balinese cooking class that will be perented by using Balinese language and will be wraped in a lovely packaged.

\section{THEORETICAL REVIEW}

Cooking class initially became popular in some countries in Europe with its uniqueness. Several hotels and restaurants has organized this program to attract their visitors. Each organizer has different program how to make it more interesting and memorable. The activities like cooking or language class is part of training that organize by several institutions. The training usually presents with the language that could be understood by the participants who join it such as Balinese, Indonesian, English, or LOTE according to request.

Training has aim to develop new skills, knowledge or expertise in cooking (Patrick, 1992). He cited that "Training is the acquisition of skills, concepts or attitudes that result in improved performance in an on-job situation (Goldstein cited by patrick, 1992)." Based on that definition could be stated that cooking or Balinese class is to develop new skills, knowledge or expertise in Balinese cooking or language class.

The Balinese cooking and language class in this study is expected to maintain Bedulu village as the area of special interest tourism destination of educational and cultural. By learning the Balinese cooking in Balinese language will create an atmosphere that is really close to Balinese culture, in turn will create a travel experience which is more experimental and memorable for the visitors.

Special Interest Tourism (SIT) is one of tourism packages that is prepared with itenerary and price according to client's request. In contranst with regular or sightseeing is prepared with trip program, intenerary and rate that is ditermined and organized with certain time (Kesrul, 2003).

Special interest tourism is defined as travelling with the primary motivation of practicing or enjoying a special interest. 
This can include unusual hobbies, activities, themes or destinations, which tend to attract niche markets. (Tourism Essay, 2015).

Special interest tourism also can be defined as the specialized tourism that involved individual or group tours by those people who wishes to develop their given interests or visit sites and places that has a relation or connection with their specific interest or subject (Smith, et al, 2016).

Tourism attrations are all the things have a unique, convenience, and value in the form of diversity wealth of natural, cultural and man-made results that were targeted or tourist visits (Pieter, 2000). The second definition was stated that tourist attraction as everything interesting and worthed to be visited and viewed (Pendit,1994).

Based on the definition above, it can be stated that tourim attraction of special interest is the tourism activities that have a relation or connection with the tourists' specific interest or subject.

Topics related to the development of tourism attraction of special interest is not a new thing therefore, there are several similar studies that need to be considered in advance are as follows:

Astawa, 2011, carried out a study entitled "The Development of Community Based on Tourism at Bedulu. $\mathrm{He}$ pointed out that Bedulu has some potential tourism to develop, firstly environment potential such as a lovely 'tukad' Petanu, the lush of Uma Telaga rice field, and has good accessibility. Bedulu has maintained the traditional and the uniqueness. The villagers have traditional life style, and several houses are connected by footpatch that has function as a way to ease villager's mobility. Secondly, cultural potential such as archeological museum which stores cultural objects (archeology) from several sites in Bali which consists of prehistory to the classical period (history) is derived from the period 2000 to 25000 years ago until century XIV - XV AD, and some old temples. Thirdly the Balinese cooking class by involving the villagers as instructors.

This program needs to be developed by giving the traning from some experts to develop their skills in handling Balinese cooking by considering hygiene and sanitation, method and cooking preparation and how to use proper tool and utensil according to hotel standard. In contrast with this study that is to develop the Balinese cooking class by considering hygiene and sanitation, method and cooking preparation and how to use proper tool and utensil according to hotel standard. It is interesting that it will present by using Balinese language to present several terminoliges in cooking such as ingredients, spices and cooking methods and preparation.

Guterres, 2014 carried out a study entitled 'The Development of Tourism Attraction Based on Community at Vatuvou, Liquisa District, Timor Leste.' This study was to develope the Vatuvou coastal as a tourist attraction due to existing potential such as beach panorama with sunset, black sandy beaches and under-sea wealth and socio-cultural potential as hospitality of the people in the village of Vatuvou, traditional activities, such as handcrafted, and rituals performed. In contrast with this study that focuses on the development of the Balinese cooking by using Balinese language in presenting it to visitors however, Indonesian, English and LOTE will be provided to help the visitors to undertand it.

\section{METHODS}

This research method is Design and Development Research. It means to desain and develop sistematically from the process of designing and developing the Balinese cooking with Balinese language and to evaluate the Balinese cooking class that has been designed and developed by considering the hygiene and sanitation standards, health, and benefit. To create an atmosphere that is really close to Balinese culture, then the cooking class will be presented in Balinese language (Richey and Klein, 2007). By presenting it in Balinese language will create a travel experience which is more experimental and memorable for the visitors.

According to Ellis and Levy (2010), there are six steps in D and $\mathrm{D}$ research can be adopted to design and develop the Balinese and language class are as follows: a) to identify the problem of Balinese cooking class that has organized by the community, b) to poin out the aim of developing Balinese and language class. It is to create a travel experience which is more experimental and memorable for the visitors,

c) to design and develop the Balinese and language class, d) to evaluate the design and development by using FGD with experts, e) to revise the result from FGD with experts f) to communicate the result by publishing this study to international journal and conference.

The data analysis of the design and development of the Balinese cooking class pointed out descriptively.

\section{RESULT}

The Balinese cooking class should be designed and developed by considering the hygiene and sanitation standards, health and benefit.

The visitors will learn how to make 'jaje Bali' and others Balinese authentic food, then they can enjoy it altogether after cooking. To create an atmosphere that is really close to Balinese culture, then the cooking class will be presented in Balinese language in accordance to create a travel experience which is more experimental and memorable for the visitors. The participants will learn several Balinese cooking terminologies such as ingredients, spices, cooking method and preparation. It is interesting that the participants will explore several ingredients and spices in the traditional market. When all of them couldn't find in the organic green house or farm for some reason.

Several communities live as farmers that utilizing the fertility of Uma Telaga rice field. Based on this stenghth the communities can utilize the fertility to grow different kind of vegetable, spices and fruit, by considering health, the can create the organic green house or farm with organic for Balinese cooking class need.

This class emphasizes several activities are as follows: 1) experiencing shopping at a local Balinese morning market, 2) 
trecking through Uma Telaga rice-paddies with amazing views and surroundings, 3) picking own vegetables and spices from the organic green house or farm. 4) trying own hand at cooking organic food without the use of electricity or gas, 5) learning from one of the best instructors or chefs in the village.

The Balinese cooking class plan is as follows:

a. Time table

\section{TABLE I. TIME TABLE}

\begin{tabular}{ll}
\hline & Morning to afternoon class \\
\hline $8: 00 \mathrm{am}$ & pick up at hotel, then visit traditional market at \\
& Bedulu \\
$10: 00 \mathrm{am}$ & short nature walk and pick up vegetables. \\
$11: 00 \mathrm{am}$ & start cooking \& lunch \\
$2: 00 \mathrm{pm}$ & drop to hotel
\end{tabular}

Afternoon to evening class:

2:00pm pick up at hotel, then visit to traditional market at Bedulu.

4:00am short nature walk and pick up vegetables.

5:00am start cooking \& dinner.

8:00pm enjoy Balinese performances (optional), drop to hotel

Important note: You can select to take a vegetarian or non-vegetarian cooking class. Language presentation is Balinese. Lets discuss for special request on presentation (Indonesian, English or LOTE).

b. Location

Organic green house or farm / puri / guest house / homestay c. Rate

TABLE II. RATE COOKING CLASS

\begin{tabular}{lll}
\hline \multicolumn{1}{c}{ Participants } & \multicolumn{1}{c}{ Duration } & \multicolumn{1}{c}{ Price/Pax } \\
\hline Adult & $8: 00-2: 00$ & IDR 425.000 \\
& Or & \\
Kid & $2: 00-20.00$ & \\
& $8: 00-2: 00$ & IDR 325.000 \\
& or & \\
& $2: 00-20.00$ & \\
\hline
\end{tabular}

Table II showed rate of Balinese cooking class

d. Cooking Class Menu

TABLE III. COOKING CLASS MENU

\begin{tabular}{|c|c|}
\hline \multicolumn{2}{|r|}{ Vegetarian menu } \\
\hline Balinese & English \\
\hline Jukut ares & banana stalk soup \\
\hline Plecing kankung & green leaves with spicy sauce \\
\hline Gado gado & vegetables with peanut sauce \\
\hline Pergedel jagung & corn fritter \\
\hline Kare tempe/tahu & tempe \& tofu coconut curry \\
\hline Tambal tomat & spicy tomato sauce \\
\hline Sambal nyuh & coconut spice \\
\hline Bubur injin & $\begin{array}{l}\text { black rice pudding and others Balinese light } \\
\text { meal. }\end{array}$ \\
\hline \multicolumn{2}{|l|}{ Non-vegetarian } \\
\hline Jukut nangka & Pork/chicken/beef \& jack fruit soup \\
\hline गикuс urao & \\
\hline
\end{tabular}

Table III showed about cooking class menu. This is a sample menu and may change depending on request

e. Cost Breakdown

Cost Breakdown is like following below:

TABLE IV. COST BREAKDOWN

Food sales $=100 \%($ sales $): 37($ persentase food cost $) \mathrm{x}$ food cost

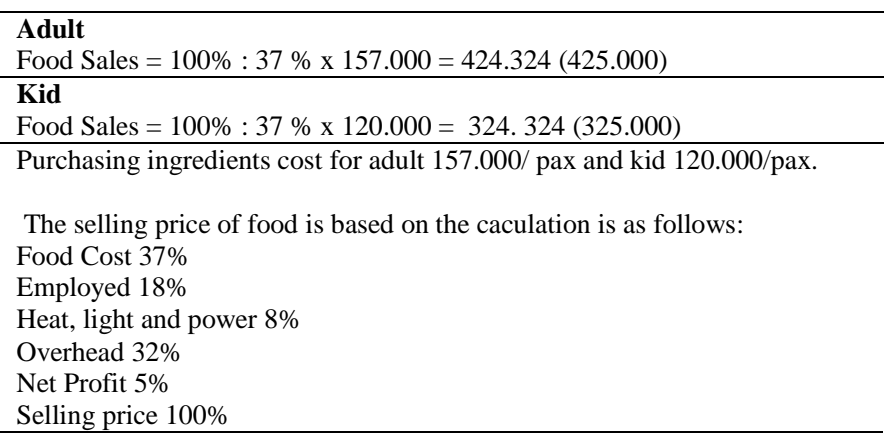

\section{f. Discussion}

This discussion considered the comparison between previous study and this study.

In contrast with this study that emphasized on designing and developing cooking class by using Balinese language. The Balinese cooking and language class has been designed and developed by considering the hygiene and sanitation standards, health and benefit. The participants will walk and pick up the organic vegetables, spices and food as the ingredients. If there is no ingredient in the organic farm or green house, the participants will explore it in traditional market. To create an atmosphere that is really close to Balinese culture, then the cooking class will be presented in Balinese language in accordance to create a travel experience which is more experimental and memorable for the visitors.

Astawa, 2011, carried out the Balinese cooking with the following package:

\begin{tabular}{|c|}
\hline 1st day \\
\hline $\begin{array}{l}\text { 1. Check in : at 'Ancak Saji Puri Bedulu.' } \\
\text { 2. Dinner by the host. }\end{array}$ \\
\hline 2nd day \\
\hline $\begin{array}{l}\text { 1. Breakfast, with 'rindik, joged, legong keraton dance } \\
\text { performances.' }\end{array}$ \\
\hline 2. Lunch \\
\hline 3. Visit carnogram at 'Kori Agung Pura Pengastulan.' \\
\hline $\begin{array}{l}\text { 4. Listen to some information at 'Pura Jero Agung' and 'Pura } \\
\text { Pengubengan.' }\end{array}$ \\
\hline 5. Visit sarcophagus. \\
\hline 6. Make 'gerabah.' \\
\hline 7. Egg painting \\
\hline $\begin{array}{l}\text { 8. Make the authentic Balinese food such as grilling satay, making } \\
\text { 'klepon.' }\end{array}$ \\
\hline 9. Visit the place of making the statue. \\
\hline $\begin{array}{l}\text { 10. Balinese cultural class such as dancing, 'mejejaitan and make } \\
\text { 'tipat.' }\end{array}$ \\
\hline $\begin{array}{l}\text { 11. Visit cultural art 'mebongbong,' and tradisonal market. } \\
\text { 12. Dinner at 'Puri Ancak Saji.' }\end{array}$ \\
\hline 3rd day: check out. \\
\hline
\end{tabular}




\section{CONCLUSION}

It can be concluded that the Balinese cooking class should be organized well by offering various activities for cooking class. It is necessary to create an experimental and memorable experience to attract the domestic or international tourists to visit Bedulu village as a tourism attraction of special interest of educational and cultural.

Bedulu is located in tourism area of Tampak SiringPanelokan-Trunyan that is well known, this is one of its strength that makes tourists easily to visit it. To attract more tourists to visit Bedulu as the area of special interest tourism destination of educational and cultural. It is really recommended that the goverment, several tourism institutions, tourism businesses and other institutions that are involved and concerned in tourism should make close and good cooperation to develop tourism in Bedulu. The recommendation can be considered is as follow:

a. The cooking class that has been organized already by the communities needs to be develop by offering the experimental and memorable experience in cooking class for the visitors, they can consider this study.

b. The communities who organized the cooking class need to improve their skill in cooking class such as the hygiene and sanitation, and health standard.

c. The communities who organized the cooking class should get the training from the experts to improve their skill in cooking method and preparation.

d. The instructors of the cooking class should have good language skill such as English and LOTE, in case the participants don't understand Balinese or Indonesian during the class, the instructor will easily to clarify it.

e. There are several activities that can be created to promote Bedulu to attract the tourist visiting it such as Balinese authentic food festival or competation, cultural event festival or Exhibition.

\section{REFERENCE}

Adikampana, I Made. (2012). Desa Wisata Berbasis Masyarakat Sebagai Model Pemberdayaan Masyarakat Di Desa Pinge, Jurnal Analisis Pariwisata UNUD (Volume. 12).

Ellis, T.J. \& Levy, Y. (2010). A Guide for Novice Researchers: Design and Development Research Methods. Proceedings of Informing Science \& IT Education Conference (InSITE) 2010.

Food in tourism: Attraction and Impediment Annals of Tourism Research, (Volume 31), Issue 4, 2004).

Guterres, CD Santos. (2014). Pengembangan Daya Tarik Wisata Berbasis Masyarakat Di Pantai Vatuvou, Distrik Liquisa, Timor Leste, Jumpa Jurnal Master Pariwisata 1, Magister Kajian Pariwisata Program Pascasarjana Universitas.

www.journals.elsevier.com/international-journal-ofgastronomy-and-foo.

Kesrul. M. (2003). Penyelenggaraan Operasi Perjalanan Wisata, Jakarta: PT. Grasindo.

Mananda, I Gusti Putu Bagus Sasrawan. (2012), Analisis Kelayakan Desa Bedulu Sebagai Desa Wisata Di Kabupaten Gianyar (Kajian Aspek Pasar Dan Pemasaran) Jurnal Analisis Pariwisata UNUD,( Vol. 12).

https://www.ukessays.com/.../tourism/nature-and-developmentof-special.

https://wisuda.unud.ac.id/.../1112025025-3-BAB\%20I.

https://www.amazon.com/Training-Research-Practice-JohnPatrick/dp/0125466609.

Pendit, S Nyoman. (1994). Ilmu Pariwisata, Jakarta Pradnya Paramita.

https://www.jcu.edu.au/_data/assets/pdf_file/.../jcudev_01271 9.pdf.

Richey, R.C. and Klein, J.D.( 2007). Design and Development Research. Lawrence Erlbaum Associate Publisher: New Jersey.

sk.sagepub.com/books/key-concepts-in-touriststudies/n37.xml.

www.le.ac.uk/oerresources/.../occpsytrainingunit1/page_03.ht $\mathrm{m}$. 